\title{
Diagnostic markers for germ cell neoplasms: from placental-like alkaline phosphatase to micro-RNAs
}

\author{
Ewa Rajpert-De Meyts, John E. Nielsen, Niels E. Skakkebæk, Kristian Almstrup \\ Department of Growth and Reproduction, Copenhagen University Hospital (Rigshospitalet), \\ Copenhagen, Denmark
}

\begin{abstract}
This concise review summarises tissue and serum markers useful for differential diagnosis of germ cell tumours (GCT), with focus on the most common testicular GCT (TGCT). GCT are characterised by phenotypic heterogeneity due to largely retained embryonic pluripotency and aberrant somatic differentiation. TGCT that occur in young men are divided into two main types, seminoma and nonseminoma, both derived from a pre-invasive germ cell neoplasia in situ (GCNIS), which originates from transformed foetal gonocytes. In severely dysgenetic gonads, a GCNIS-resembling lesion is called gonadoblastoma. GCT occur rarely in young children (infantile GCT) in whom the pathogenesis is different (no GCNIS/gonadoblastoma stage) but the histopathological features are similar to the adult GCT. The rare spermatocytic tumour of older men is derived from post-pubertal spermatogonia that clonally expand due to gain-of function mutations in survival-promoting genes (e.g. FGFR3, $H R A S$ ), thus this tumour has a different expression profile than GCNIS-derived TGCT.

Clinically most informative immunohistochemical markers for GCT, except teratoma, are genes expressed in primordial germ cells/gonocytes and embryonic pluripotency-related factors, such as placental-like alkaline phosphatase (PLAP), OCT4 (POU5F1), NANOG, AP-2 $\gamma$ (TFAP2C) and LIN28, which are not expressed in normal adult germ cells. Some of these markers can also be used for immunocytochemistry to detect GCNIS or incipient tumours in semen samples.

Gene expression in GCT is regulated in part by DNA and histone modifications, and the epigenetic profile of these tumours is characterised by genome-wide demethylation, except nonseminomas. In addition, a recently discovered mechanism of post-genomic gene expression regulation involves small non-coding RNAs, predominantly micro-RNA (miR). Testicular GCT display micro-RNA profiles similar to embryonic stem cells. Targeted miRNA-based blood tests for miR-371-3 and miR-367 clusters are currently under development and hold a great promise for the future. In some patients miR-based tests may be even more sensitive than the classical serum tumour markers, $\beta$-chorio-gonadotrophin ( $\beta$-hCG), $\alpha$-fetoprotein (AFP) and lactate dehydrogenase (LDH), which are currently used in the clinic.

In summary, research advances have provided clinicians with a panel of molecular markers, which allow specific diagnosis of various subtypes of GCT and are very useful for early detection at the precursor stage and for monitoring of patients during the follow-up. (Folia Histochemica et Cytobiologica 2015, Vol. 53, No. 3, 177-188)
\end{abstract}

Key words: testis; germ cell neoplasia; testicular cancer; seminoma; embryonal carcinoma; carcinoma in situ; testis; spermatocytic tumour; tumour marker; PLAP; AP- $2 \gamma$; micro-RNA; immunohistochemistry

Correspondence address: E. Rajpert-De Meyts, M.D., Ph.D.

Department of Growth and Reproduction

Rigshospitalet, Section GR-5064

DK-2100 Copenhagen, Denmark

tel.: +45 3545-5017, fax: +45 3545-6054

e-mail: erm@rh.dk
Abbreviations: AFP $-\alpha$-fetoprotein, CIS - carcinoma in situ testis (currently GCNIS), DSD — disorders of sex development, EC - embryonal carcinoma, GCNIS - germ cell neoplasia in situ (previously CIS), GCT - germ cell tumour, $\beta$-hCG $-\beta$-chorio-gonadotrophin, $\mathrm{LDH}$ - lactate dehydrogenase, PGC - primordial germ cell, TDS - testicular dysgenesis syndrome, TGCT — testicular germ cell tumour 


\section{Introduction}

Germ cell tumours (GCT) are a group of neoplasms with some unusual features in comparison to solid cancers that are derived from somatic cells. A striking feature of GCT is their phenotypic heterogeneity, due to retained embryonic pluripotency and subsequent aberrant somatic differentiation in a subset of these tumours, known as teratomas. This morphological heterogeneity has been causing difficulties in classification and histopathological diagnosis. During the recent decades, thanks to new tools of molecular biology, GCT have been characterised in greater detail and a number of novel diagnostic markers have been developed. In this article, we summarise research developments concerning histogenesis of different types of GCT and review immunohistochemical and serum markers which are clinically useful for differential diagnosis of GCT and their precursors.

Germ cell tumours can occur in any age, both in men and women. The tumours arise most often in the gonads but can be found in extragonadal locations, usually close to the midline of the body [1]. Malignant GCT are much more frequent in males, which can be explained by differences in biology of male and female germ cells, especially during development $[2,3]$. In males, germ cell-derived malignancies occur predominantly in the testis, thus testicular GCT (TGCT) are the focus of this review.

\section{Histopathology and pathogenesis of germ cell neoplasms}

Germ cell tumours in males occur in three age groups, and in each age group the tumours are derived from a different stage of germ cell development, as illustrated in Figure 1.

The most common by far are TGCT that affect post-pubertal adolescents and young adults. Testicular tumours in this age group are derived from a pre-invasive stage, germ cell neoplasia in situ (GCNIS); a new term proposed by the most recent edition of World Health Organisation Classification of Tumours of the Male Genital Organs, which will be published in 2016. Previously used names were testicular carcinoma in situ (CIS) [4], intratubular germ cell neoplasia, unclassified (IGCNU) and testicular intraepithelial neoplasia (TIN). In severely dysgenetic gonads of individuals with disorders of sex development (DSD), the precursor lesion most often seen is gonadoblastoma. Depending on the degree of masculinisation of the gonad, either GCNIS or gonadoblastoma, or a mixture of both, may be present. GCNIS is enclosed in better masculinised tubules, while gonadoblastoma resides in nests of granulosa-resembling cells, but the neoplastic germ cells have essentially the same phenotypic features [5-7]. A good marker for more masculinised Sertoli cells is SOX9, whereas granulosa-like cells surrounding gonadoblastoma cells express FOXL2 [8].

It is important for the understanding of the pathogenesis of GCNIS-derived TGCT that even though most of the patients are normally virilised males, these neoplasms are associated with disturbed early development of the testis, often manifested in adulthood as clusters of poorly formed tubules, undifferentiated Sertoli cells, microlithiasis and Leydig cells micronodules [9]. Among the risk factors for GCNIS/TGCT, cryptorchidism, genital malformations, low percentage sex chromosome aneuploidy and some forms of infertility, are also linked to disturbed foetal development, hence all these conditions have been grouped within testicular dysgenesis syndrome (TDS) [10]. The incidence of TGCT and some other TDS disorders have been increasing around the word, suggesting a strong environmental component in the pathogenesis, but combined with genetic susceptibility [10-12]. Discussion on the aetiology of TGCT and TDS exceeds the scope of this review, so the readers are referred to recent comprehensive review articles on this topic [11, 13, 14].

TGCT of young adults are divided into two histological entities: seminoma and nonseminoma, but a combination of the above subtypes in one patient is quite common [15]. Seminoma is the most frequent type of these tumours (approximately $60 \%$ of cases) and consists of malignant germ cells that retain a germ cell phenotype similar to GCNIS/gonadoblastoma cells. Nonseminomas display a very heterogeneous histology and are usually composed of mixtures of embryonal carcinoma, mature or immature teratoma, choriocarcinoma and yolk sac tumour (also known as endodermal sinus tumour), although in rare cases these components may occur in a pure form [15].

Embryonal carcinoma is considered a reprogrammed and transformed equivalent of embryonic stem cells and is characterised by pluripotency, which explains the presence of somatic cells within teratomatous components, which are at differentiation stages that mimic embryonic development [16]. Although this review focusses on male GCT, it is important to mention that essentially the same histological entities are recognised in females where they occur mainly in the ovary but may also arise in extragonadal locations. The ovarian and extragonadal counterparts of seminoma are dysgerminoma (may be accompanied by gonadoblastoma in females with some Y-chromosome material in their genome) and germinoma, respective- 


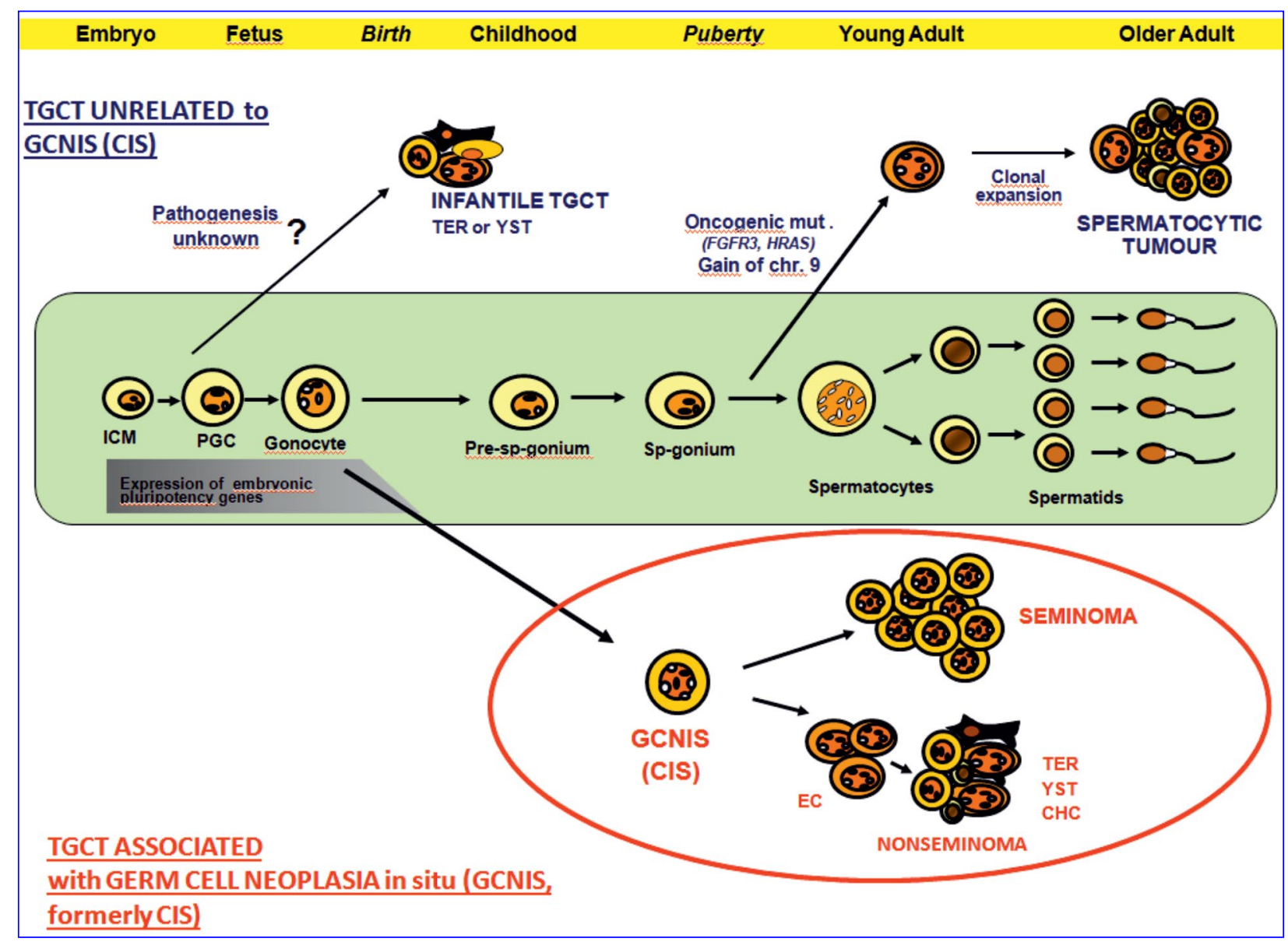

Figure 1. Schematic histogenesis of testicular germ cell tumours (TGCT) in relation to the normal development of germ cells. Normal germ cell development is shown in the green-shaded middle part of the Figure. Rare TGCT that are unrelated to germ cell neoplasia in situ (GCNIS); infantile TGCT and spermatocytic tumour are shown in the upper part of the graph. The most common TGCT that are derived from foetal germ cells (gonocytes) via the stage of GCNIS are shown in the lower part of the Figure within the red ellipse. Abbreviations: CHC - choriocarcinoma; EC - embryonal carcinoma; ICM — inner cell mass; PGC — primordial germ cell; TER — teratoma; YST — yolk sac tumour

ly, while the equivalent of nonseminoma in a female is nondysgerminoma, or simply malignant teratoma, if no other component is present [3].

Regardless of the gender, location and pathogenesis, all the above mentioned GCT have similar molecular features. The GCT genome is characterised by polyploidisation and the presence of genomic gain of the short arm of chromosome 12p, often in the form of an isochromosome, $\mathrm{i}(12 \mathrm{p})$ and a relative excess of the $\mathrm{X}$ chromosome (reviewed in $[1,3,17]$. The presence of $i(12 p)$ is considered pathognomonic for the germ cell origin of a tumour and is useful in differential diagnosis $[18,19]$.

TGCT in other age groups are rare. Childhood TGCT occur typically in infants and toddlers up to 5 years of age, and histology at this age is either mature teratoma or yolk sac tumour [1, 20,21]. Importantly, there is no GCNIS- or gonadoblastoma-like precursor lesion, suggesting that these tumours originate directly from PGC; however, the pathogenesis remains unknown $[22,23]$. These tumours, mainly mature teratomas, may also occasionally be found in adult men beyond childhood, and can be distinguished from malignant TGCT of young adults by the absence of GCNIS and lack of gain of $12 p[24,25]$.

The third type of TGCT, which occurs in older men, with mean age of diagnosis around $50-55$ years of age is spermatocytic tumour, previously known as spermatocytic seminoma [1, 26-28]. This tumour arises exclusively in the testis (no ovarian counterpart) and is not associated with GCNIS [29]. Spermatocytic tumour originates from post-pubertal spermatogonia which expand clonally due to gain-of-function mutations in genes involved in pathways that increase spermatogonial survival/proliferation, e.g. FGFR3 and $H R A S$ [30]. Spermatocytic tumour is characterised 
by frequent amplification of a locus on the $\mathrm{p}$ arm of chromosome 9, with DMRT1 as a candidate gene [27].

\section{Immunohistochemical markers useful for GCT diagnosis in tissue specimens}

The first histochemical marker for GCNIS and GCNIS-derived TGCT was placental-like alkaline phosphatase (PLAP), previously widely used in animal models to detect PGCs [31]. The long postulated by our group similarity of GCNIS cells to foetal gonocytes [32] was first supported by immunohistochemical studies which looked at one or few proteins at the time [33-36]. Subsequently, a genome-wide microarray study corroborated this hypothesis by a direct comparison of GCNIS and gonocyte transcriptomes [37].

Likewise, pluripotent characteristics of GCT observed previously by pathologists, has been demonstrated by molecular studies, including numerous microarray studies, which detected in these tumours (excluding teratoma) as well as in human PGCs/gonocytes, a high expression of embryonic factors involved in pluripotency regulation, such as POU5F1(OCT4), NANOG, SOX2, REX1, UTF1 or LIN28 [38-47]. These studies have also identified differences between the GCT subtypes, e.g. seminoma/(dys)germinoma versus embryonal carcinoma or yolk sac tumour. It is not possible to list here all studies and all implicated genes, so the interested reader should consult recent systematic review articles [3, 48].

The above-mentioned studies provided a range of markers that have been validated for the identification of GCNIS and seminoma/(dys)germinoma in tissue specimens by immunohistochemistry, including OCT4 [36, 39, 49, 50], NANOG [51, 52], LIN28 [47, 53], AP-2 [54-56], podoplanin (PDPN, M2A, D2-40, Aggrus) [57, 58], and KIT [33]. The markers that are useful in clinical practice and research are listed in Table 1. Immunohistochemistry is very helpful for the detection of GCNIS in testicular biopsies [59-61] and we suggest using at least two different markers for each tissue specimen, e.g. PLAP and OCT4 or PDPN (Figure 2).

For differential diagnosis of nonseminomas, a panel of several markers has to be used in order to identify the presence of different histological components, as shown in Table 1. For the detection of embryonal carcinoma, pluripotency markers OCT4 and NANOG are useful, but additional discriminative markers are needed to distinguish it from seminoma. We suggest to use SOX2 [43, 44, 62, 63] (Figure 3) or CD30 (both are positive in embryonal carcinoma but negative in seminoma), simultaneously with KIT or PDPN (positive in seminoma but negative in embryonal carcinoma) [64, 65]. Differentiated somatic elements within teratomas have expression profiles of various tissue lineages and no longer express pluripotency factors or germ cell-specific genes.

Extraembryonic components yolk sac tumour and choriocarcinoma are usually admixed with other nonseminomatous elements, but may occur as pure tumours, especially in children. Regardless of the age and gender of the patient, these components have essentially the same morphology and expression profiles $[3,21,43,48,65]$. Yolk sac tumour produces and secrets $\alpha$-fetoprotein (AFP), which is detectable in serum and tumour tissue [66]. Among other immunohistochemical markers for yolk sac tumour the most informative are Glypican-3 (GPC3) and SALL4 [65, 67, 68] (Figure 3). Choriocarcinoma contains trophoblastic-like syncytia and secrets $\beta$-chorio-gonadotrophin $(\beta$-hCG) which is measurable in serum and detectable in tissues [66]. Other immunohistochemical markers, such as GPC3 or SALL4 are present but are not specific for choriocarcinoma [69].

As far as spermatocytic tumour of older men is concerned, its gene expression profile - both at the transcript and protein level - resembles closely profiles of spermatogonia and early primary spermatocytes of the adult testis [26, 27, 70]. Accordingly, spermatocytic tumours do not express embryonic pluripotency genes and PGC/gonocyte specific markers, and markers of haploid spermatids (e.g. p19-INK4) are also negative [26]. Among the best markers for spermatocytic tumour are the so-called cancer-testis antigens: SSX1-4, MAGE-A4, MAGE3, NY-ESO-1/CTAG1A, GAGE4, SAGE1 [27, 70-74] (Figure 3). Other immunohistochemical markers include SYCP1, NSE (neuron-specific enolase), CHK2, VASA, UTF1, FGFR3 or HRAS, and DMRT1 [26, 27, 30, 46, 71]. Recently, OCT2 was detected in a small subset of spermatocytic tumours and in A-dark spermatogonia [70], and in both cell types, OCT2 was found mutually exclusive with DMRT1 [75]. For diagnostic purposes in the clinics we suggest MAGE-A4 (Figure 3) and DMRT1, which are the most robust immunohistochemical markers, as shown in Table 1.

\section{Detection of GCNIS in semen samples by immunocytochemistry and histochemistry}

Like other precancerous in situ changes, GCNIS can be detected before the invasive tumour has developed. This happens only rarely, mainly in patients who undergo testicular biopsies because of an increased risk of TGCT, such as DSD, contralateral testicular cancer, history of cryptorchidism or infertility, in particular if the testes are small and microlithasis is 


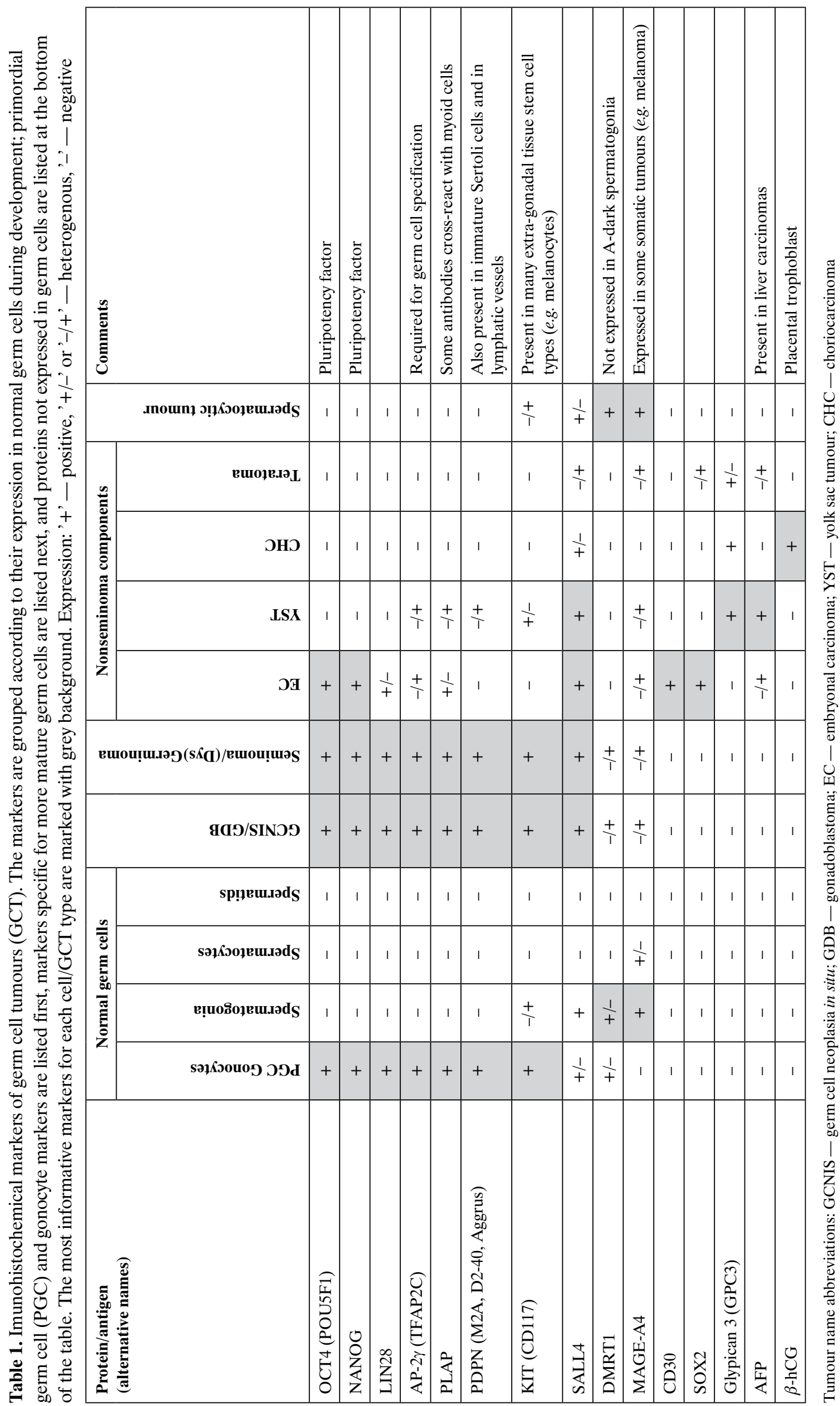



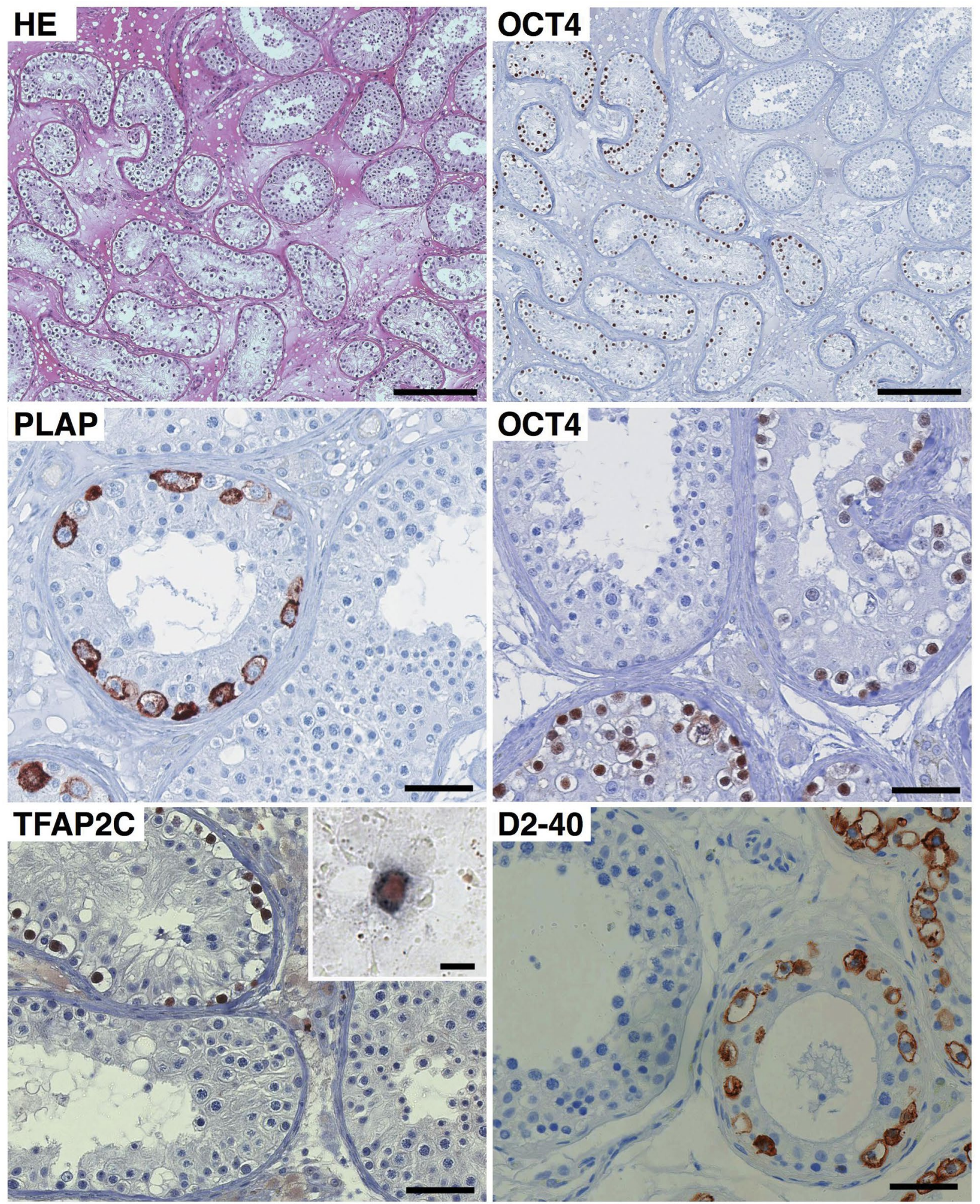

Figure 2. Germ cell neoplasia in situ (GCNIS): histology and selected immunohistochemical markers. The two top microphotographs are haematoxylin-eosin (HE)-stained (left) and OCT4-stained (right), serial sections of an adult testis specimen with GCNIS (visible on the left of both images) and tubules with normal spermatogenesis (on the right); scale bar $=250 \mu \mathrm{m}$. The staining for OCT4 clearly helps to detect GCNIS. Sections stained with four commonly used immunohistochemical markers (PLAP, OCT4, TFAP2C and D2-40) are shown at higher magnification below; scale bar $=50 \mu \mathrm{m}$. Tubules with GCNIS are shown side-by-side to tubules with ongoing spermatogenesis. Note an insert in the micrograph with TFAP2C (also known as AP-2 $\gamma$ ), showing a GCNIS cell in a semen smear positive for TFAP2C (red colour, in the nucleus) and displaying a strong enzymatic reaction of alkaline phosphatase (blue colour, in the cytoplasm); scale bar $=10 \mu \mathrm{m}$ 



Figure 3. Examples of immunohistochemical markers for different histological subtypes of testicular germ cell tumours. From the top: D2-40 in a seminoma (SEM), there are also two tubules with germ cell neoplasia in situ (GCNIS) visible; MAGE-A4 in a spermatocytic tumour (SPT), SOX2 and OCT4 in embryonal carcinoma (EC) containing differentiated teratomatous tissues (TER), the latter component negative for both markers, SALL4 and AFP in two different specimens of yolk sac tumours (YST). Scale bar $=100 \mu \mathrm{m}$ 
visible on ultrasound examination [59, 60, 76, 77]. Giwercman was the first to demonstrate that GCNIS cells are occasionally exfoliated into semen and can be identified in the ejaculate by immunostaining for M2A/PDPN antigen [78]. However, cell surface markers were not optimal for this purpose, so more recently, we and others have exploited nuclear proteins, AP- $2 \gamma$ or OCT4, which ought to be better protected from degradation in semen $[79,80]$. The test was promising but had rather low sensitivity and required good experience to distinguish cells which were truly positive from occasionally false positive cells [79]. In another study from France, cancer-testis antigens, MAGE-A4 and NY-ESO- 1 have been tested for suitability for detecting GCNIS cells in semen [81]. However, a serious drawback of this approach is that both antigens are also expressed in normal germ cells (spermatogonia and early primary spermatocytes), thus leading to false-positive results in healthy subjects. Subsequently, our group has improved sensitivity of the AP- $2 \gamma$-based test by combining it with rapid histochemical staining detecting enzymatic activity of PLAP [82]. The double-staining method was further optimised by automated staining, slide scanning and imaging software, which increased the speed and objectivity of the test [83]. An example of GCNIS cells detected by this method is shown as an insert in Figure 1. This approach is reliable in experienced hands, but the sensitivity of the assay remains low, because GCNIS cells in many patients do not readily exfoliate into semen. It follows that a negative result does not completely exclude the presence of a neoplasm in a testicle. However, the test is much less invasive that a surgical biopsy and can be performed repeatedly, so it may be considered to monitor for GCNIS also those patients who do not have a stringent indication for testicular biopsy.

\section{Immunohistochemical markers of epigenetic modifications in TGCT}

In addition to the embryonic gene expression pattern, epigenetic profiles of neoplastic germ cells resemble those of primordial germ cells (PGCs) and foetal gonocytes to a large extent $[84,85]$. DNA methylation and histone modifications in GCNIS and TGCT are different from somatic cells, but also strikingly variable. Consistent DNA demethylation throughout the genome is observed in GCNIS and seminoma, whereas the genome of non-seminomas is methylated in a non-random manner with imprinted genes left hypo-methylated [85-88]. This can be easily demonstrated in tissue specimens by immunohistochemical staining for 5-methyl-cytosine [84, 87].
The hypomethylation of GCNIS is apparently actively maintained by expression of APOBEC1 and base excision repair proteins MBD4, APEX1 and PARP1 [89]. A very different picture is displayed by spermatocytic tumour which originates from clonally-expanding mature spermatogonia, where hypo- and hyper-methylated cells can be seen admixed next to each other, in a seemingly chaotic pattern [90].

In addition to DNA methylation, modifications of histones in nuclear chromatin are another mechanism of gene expression regulation. Histone modifications are variable in TGCT and can also be detected by immunohistochemistry. GCNIS cells are characterised by the virtual absence of restrictive histone modifications $\mathrm{H} 3 \mathrm{~K} 9 \mathrm{me} 2 / 3$ and $\mathrm{H} 3 \mathrm{~K} 27 \mathrm{me} 3$, and the abundance of $\mathrm{H} 3 \mathrm{~K} 4 \mathrm{me} 1, \mathrm{H} 3 \mathrm{~K} 4 \mathrm{me} 2 / 3, \mathrm{H} 3 \mathrm{~K} 9 \mathrm{ac}$ and the histone variant $\mathrm{H} 2 \mathrm{~A}$.Z, which are all modifications associated with active and permissive chromatin structure [84, 91]. Moreover, GCNIS cells show high levels of H4/ /H2AR3me2 and simultaneously express BLIMP1/ /PRMT5, which is essential for PGC specification [92]. We hypothesise that the DNA hypo-methylation, the absence of DNA damage response and a high proliferation rate combined with 'permissive' chromatin modifications may render GCNIS vulnerable to genomic instability and increased plasticity in response to exogenous factors [93].

\section{Traces of GCT in blood: classical biochemical markers and micro-RNAs}

Diagnosis of GCT in the clinic involves an obligatory step of taking a blood sample to measure by immunoassays a set of biochemical tumour markers; $\beta$-hCG, AFP and (in some centres) lactate dehydrogenase (LDH, LD-1) [94, 95]. These markers are helpful in the diagnosis and monitoring of GCT and are included in commonly used staging manuals. AFP and $\beta$-hCG are secreted by nonseminomatous tumours, yolk sac tumour and syncytiotrophoblast of choriocarcinoma (as mentioned above in the section on immunohistochemical markers), whereas LDH is also secreted by seminoma. The presence of just a few giant cells in a seminoma may be sufficient to detect $\beta$-hCG in serum. LDH levels in serum may be increased if the tumour has a prominent gain of chromosome $12 \mathrm{p}$, where the $L D H B$ gene is located [96]. The interpretation of serum levels of these markers in patients with seminoma, pure EC and teratoma is sometimes difficult, and many cases are marker-negative.

However, it can be expected that a new blood tests will become soon available. A recently discovered mechanism of post-genomic gene expression regulation involves small non-coding RNAs, predominantly 
micro-RNA (miRNA or miR), which are among the smallest ( $\sim 22$ bases long) RNAs, thus much less prone to degradation. MiRNAs inhibit gene expression by direct base-pairing with transcripts, and one miRNA may have many targets. These small RNAs act inside the cells, but recently it has become clear that miRNAs are actively secreted in exosome vesicles that can affect post-transcriptional regulation in a remote recipient cell. GCT display micro-RNA profiles similar to embryonic stem cells, and these embryonic miRNA types are already highly upregulated and detectable in pre-invasive GCNIS cells [97]. Interestingly, the characteristic miRNA profiles are similar in GCT that arise in children and adults, and are detectable in all histological subtypes and components, except teratoma $[21,98,99]$. This specific TGCT profile, which was detected by several groups independently from each other, includes a high level of miR-371-3 cluster, miR-302 and miR-367. Tests targeting these specific miRNAs are currently under development. Preliminary studies have already proven great specificity (99-100\%) and sensitivity of these tests for the detection of TGCT [100-102]. Other body fluids are also suitable for detection of miRNA released by disseminated tumours, e.g. pleural effusion fluid. Importantly for testicular neoplasms, seminal plasma apparently also has elevated levels of specific miRNAs compared with controls [103]. These results are very promising and it is likely that miRNA-based assays will be routinely used for diagnosis and follow-up of the patients in not so distant future.

\section{Conclusions}

In conclusion, research advances over the years have provided clinicians with a panel of molecular markers, which allow specific diagnosis of germ cell tumours in a clinical laboratory setting. Immunohistochemical and histochemical markers in tissues remain used and are still the gold standard for pathology diagnosis. However, the existing biochemical serum assays will soon be supported - and in the future perhaps replaced - by novel more sensitive and specific tests that detect circulating products of tumour cells and are likely to improve early detection and monitoring of patients.

\section{References}

1. Oosterhuis JW, Looijenga LH. Testicular germ-cell tumours in a broader perspective. Nat Rev Cancer. 2005;5:210-222. doi: $10.1038 / \mathrm{nrc} 1568$.

2. Stang A, Trabert B, Wentzensen $\mathrm{N}$ et al. Gonadal and extragonadal germ cell tumours in the United States, 1973-2007. Int J Androl. 2012;35:616-625. doi: 10.1111/j. 1365-2605.2011.01245.x.
3. Kraggerud SM, Hoei-Hansen CE, Alagaratnam S et al. Molecular characteristics of malignant ovarian germ cell tumours and comparison to testicular counterparts: implications for pathogenesis. Endocrine Rev. 2013;34:339-376. doi: 10.1210/ /er.2012-1045.

4. Skakkebaek NE. Possible carcinoma-in-situ of the testis. Lancet. 1972;2:516-517. PMID: 4115573.

5. Guminska A, Oszukowska E, Kuzanski W et al. Less advanced testicular dysgenesis is associated by a higher prevalence of germ cell neoplasia. Int J Androl. 2010;33:e153-e162. doi: 10.1111/j.1365-2605.2009.00981.x.

6. Chemes HE, Venara M, Del Rey G et al. Is a CIS phenotype apparent in children with Disorders of Sex Development? Milder testicular dysgenesis is associated with a higher risk of malignancy. Andrology. 2015;3:59-69. doi: 10.1111/andr.301.

7. van der Zwan YG, Biermann K, Wolffenbuttel KP, Cools M, Looijenga LH. Gonadal maldevelopment as risk factor for germ cell cancer: towards a clinical decision model. Eur Urol. 2015;67:692-701. doi: 10.1016/j.eururo.2014.07.011.

8. Hersmus R, Kalfa N, de Leeuw B et al. FOXL2 and SOX9 as parameters of female and male gonadal differentiation in patients with various forms of disorders of sex development (DSD). J Pathol. 2008;215:31-38. doi: 10.1002/path.2335.

9. Hoei-Hansen CE, Holm M, Rajpert-De Meyts E, Skakkebæk NE. Histological evidence of testicular dysgenesis in contralateral biopsies of 218 patients with testicular germ cell cancer. J Pathol. 2003;200:370-374. PMID: 12845633.

10. Skakkebæk NE, Rajpert-De Meyts E, Main KM. Testicular dysgenesis syndrome: an increasingly common developmental disorder with environmental aspects. Hum Reprod. 2001;16:972-978. doi: 10.1093/humrep/16.5.972.

11. Rajpert-De Meyts E. Developmental model for the pathogenesis of testicular carcinoma in situ: Environmental and genetic aspects. Hum Reprod Update. 2006;12:303-323. doi: 10.1093/humupd/dmk006.

12. Znaor A, Lortet-Tieulent J, Jemal A, Bray F. International variations and trends in testicular cancer incidence and mortality. Eur Urol. 2014;65:1095-1106. doi: 10.1016/j.eururo.2013.11.004.

13. Looijenga LH, Van Agthoven T, Biermann K. Development of malignant germ cells - the genvironmental hypothesis. Int J Dev Biol. 2013;57:241-253. doi: 10.1387/ijdb.1300261l.

14. Juul A, Almstrup K, Andersson A-M et al. Possible fetal determinants of male infertility. Nature Rev Endocrinol. 2014;10:553-562. doi: 10.1038/nrendo.2014.97.

15. Ulbright TM, Amin MB, Young RH (eds.). Atlas of Tumor Pathology. Tumors of the testis, adnexa, spermatic cord, and scrotum. Armed Forces Institute of Pathology, Washington DC, USA, 1999;1-385.

16. Skotheim RI, Lind GE, Monni O et al. Differentiation of human embryonal carcinomas in vitro and in vivo reveals expression profiles relevant to normal development. Cancer Res. 2005;65:5588-5598. doi: 10.1158/0008-5472.CAN-05-0153.

17. Boublikova L, Buchler T, Stary J, Abrahamova J, Trka J. Molecular biology of testicular germ cell tumors: unique features awaiting clinical application. Crit Rev Oncol Hematol. 2014;89:366-385. doi: 10.1016/j.critrevonc.2013.10.001.

18. Atkin NB, Baker MC. i(12p): specific chromosomal marker in seminoma and malignant teratoma of the testis? Cancer Genet Cytogenet. 1983;10:199-204. PMID: 6616439.

19. Looijenga LH, Zafarana G, Grygalewicz B et al. Role of gain of $12 \mathrm{p}$ in germ cell tumour development. APMIS. 2003;111:161-171. PMID: 12752258. 
20. Ahmed HU, Arya M, Muneer A, Mushtaq I, Sebire NJ. Testicular and paratesticular tumours in the prepubertal population. Lancet Oncol. 2010;11:476-483. doi: 10.1016/ S1470-2045(10)70012-7.

21. Murray MJ, Nicholson JC, Coleman N. Biology of childhood germ cell tumours, focussing on the significance of microRNAs. Andrology. 2015;3:129-139. doi: 10.1111/andr.277.

22. Jørgensen N, Müller J, Giwercman A, Visfeldt J, Müller H, Skakkebæk NE. DNA content and expression of tumour markers in germ cells adjacent to germ cell tumours in childhood: probably a different origin for infantile and adolescent germ cell tumours. J Pathol. 1995;176:269-278. PMID: 7674089.

23. Mosbech CH, Rechnitzer C, Brok JS, Rajpert-De Meyts E, Hoei-Hansen CE. Recent advances in understanding the etiology and pathogenesis of pediatric germ cell tumors. J Ped Hematol Oncol. 2014;36:263-270. doi: 10.1097/ MPH.0000000000000125.

24. Zhang C, Berney DM, Hirsch MS, Cheng L, Ulbright TM. Evidence supporting the existence of benign teratomas of the postpubertal testis: a clinical, histopathologic, and molecular genetic analysis of 25 cases. Am J Surg Pathol. 2013;37:827-835. doi: 10.1097/PAS.0b013e31827dcc4c.

25. Oosterhuis JW, Stoop JA, Rijlaarsdam MA et al. Pediatric germ cell tumors presenting beyond childhood? Andrology. 2015;3:70-77. doi: 10.1111/andr.305.

26. Rajpert-De Meyts E, Jacobsen GK, Bartkova J et al. The immunohistochemical expression pattern of Chk2, p53, p19-INK4d, MAGE-A4 and other selected antigens provides new evidence for the pre-meiotic origin of spermatocytic seminoma. Histopathology. 2003;42:217-226. PMID: 12605640.

27. Looijenga LH, Hersmus R, Gillis AJ et al. Genomic and expression profiling of human spermatocytic seminomas: primary spermatocyte as tumorigenic precursor and DMRT1 as candidate chromosome 9 gene. Cancer Res. 2006;66:290-302. PMID: 16397242.

28. Carrière P, Baade P, Fritschi L. Population based incidence and age distribution of spermatocytic seminoma. $J$ Urol. 2007;178:125-128. PMID: 17499277.

29. Müller J, Skakkebæk NE, Parkinson MC. The spermatocytic seminoma: views on pathogenesis. Int J Androl. 1987;10:147-156. PMID: 3583416.

30. Goriely A, Hansen RM, Taylor IB et al. Activating mutations in FGFR3 and HRAS reveal a shared genetic origin for congenital disorders and testicular tumors. Nat Genet. 2009;41:1247-1252. doi: 10.1038/ng.470.

31. Jacobsen GK, Nørgaard-Pedersen B. Placental alkaline phosphatase in testicular germ cell tumours and in carcinoma-in-situ of the testis. Acta Pathol Microbiol Scand A. 1984;92:323-329. PMID: 6209917.

32. Skakkebæk NE, Berthelsen JG, Giwercman A, Müller J. Carcinoma-in-situ of the testis: possible origin from gonocytes and precursor of all types of germ cell tumours except spermatocytoma. Int J Androl. 1987;10:19-28. PMID: 3034791.

33. Rajpert-De Meyts E, Skakkebæk NE. Expression of the c-kit protein product in carcinoma-in situ and invasive testicular germ cell tumours. Int J Androl. 1994;17:85-92. PMID: 7517917.

34. Jørgensen N, Rajpert-De Meyts E, Graem N, Müller J, Giwercman A, Skakkebæk NE. Expression of immunohistochemical markers for testicular carcinoma in situ by normal human fetal germ cells. Lab Invest. 1995;72:223-231. PMID: 7531795.

35. Rajpert-De Meyts E, Bartkova J, Samson M et al. The emerging phenotype of the testicular carcinoma in situ germ cell. APMIS. 2003;111:267-279. PMID: 12752272.
36. Honecker F, Stoop H, de Krijger RR, Lau Y-FC, Bokemeyer C, Looijenga LH. Pathobiological implications of the expression of markers of testicular carcinoma in situ by fetal germ cells. J Pathol. 2004;203:849-857. PMID: 15221945.

37. Sonne SB, Almstrup K, Dalgaard M et al. Analysis of gene expression profiles of microdissected cell populations indicates that testicular carcinoma in situ is an arrested gonocyte. Cancer Res. 2009;69:5241-5250. doi: 10.1158/0008-5472. CAN-08-4554.

38. Skotheim RI, Monni O, Mousses S et al. New insights into testicular germ cell tumorigenesis from gene expression profiling. Cancer Res. 2002;62:2359-2364. PMID: 11956097.

39. Looijenga LH, Stoop H, de Leeuw HP et al. POU5F1 (OCT3/4) identifies cells with pluripotent potential in human germ cell tumors. Cancer Res. 2003;63:2244-2250. PMID: 12727846.

40. Sperger JM, Chen X, Draper JS et al. Gene expression patterns in human embryonic stem cells and human pluripotent germ cell tumors. Proc Natl Acad Sci USA. 2003;100:13350-13355. PMID: 14595015.

41. Almstrup K, Hoei-Hansen CE, Wirkner U et al. Embryonic stem cell-like features of testicular carcinoma in situ revealed by genome-wide gene expression profiling. Cancer Res. 2004;64:4736-4743. PMID: 15256440.

42. Juric D, Sale S, Hromas RA et al. Gene expression profiling differentiates germ cell tumors from other cancers and defines subtype-specific signatures. Proc Natl Acad Sci USA. 2005;102:17763-17768. PMID: 16306258.

43. Korkola JE, Houldsworth J, Chadalavada RS et al. Down-regulation of stem cell genes, including those in a $200-\mathrm{kb}$ gene cluster at 12p13.31, is associated with in vivo differentiation of human male germ cell tumors. Cancer Res. 2006;66:820-827. PMID: 16424014.

44. Biermann K, Heukamp LC, Steger K et al. Genome-wide expression profiling reveals new insights into pathogenesis and progression of testicular germ cell tumors. Cancer Genomics Proteomics. 2007;4:359-367. PMID: 17993720.

45. Gashaw I, Dushaj O, Behr R et al. Novel germ cell markers characterize testicular seminoma and fetal testis. Mol Hum Reprod. 2007;13:721-727. PMID: 17785371.

46. Kristensen DM, Nielsen JE, Skakkebæk NE et al. Presumed pluripotency markers UTF-1 and REX-1 are expressed in human adult testes and germ cell neoplasms. Hum Reprod. 2008;23:775-782. doi: 10.1093/humrep/den010.

47. West JA, Viswanathan SR, Yabuuchi A et al. A role for Lin28 in primordial germ-cell development and germ-cell malignancy. Nature. 2009;460:909-913. doi: 10.1038/nature08210.

48. Alagaratnam S, Lind GE, Kraggerud SM, Lothe RA, Skotheim RI. The testicular germ cell tumour transcriptome. Int J Androl. 2011;34:e133-e150. doi: 10.1111/j.1365-2605.2011. 01169.x.

49. Rajpert-De Meyts E, Hanstein R et al. Developmental expression of POU5F1 (OCT-3/4) in normal and dysgenetic human gonads. Hum Reprod. 2004;19:1338-1344. PMID: 15105401.

50. Jones TD, Ulbright TM, Eble JN, Cheng L. OCT4: A sensitive and specific biomarker for intratubular germ cell neoplasia of the testis. Clin Cancer Res. 2004;10:8544-8547. PMID: 15623637.

51. Hoei-Hansen CE, Almstrup K, Nielsen JE et al. Stem cell pluripotency factor NANOG is expressed in human fetal gonocytes, testicular carcinoma in situ and germ cell tumours. Histopathology. 2005;47:48-56. PMID: 15982323.

52. Hart AH, Hartley L, Parker K et al. The pluripotency homeobox gene NANOG is expressed in human germ cell tumors. Cancer. 2005;104:2092-2098. PMID: 16206293. 
53. Cao D, Liu A, Wang $\mathrm{F}$ et al. RNA-binding protein LIN28 is a marker for primary extragonadal germ cell tumors: an immunohistochemical study of 131 cases. Mod Pathol. 2011;24:288-296. doi: 10.1038/modpathol.2010.195.

54. Hoei-Hansen CE, Nielsen JE, Almstrup Ket al. Transcription factor AP-2gamma is a developmentally regulated marker of testicular carcinoma in situ and germ cell tumors. Clin Cancer Res. 2004;10:8521-8530. PMID: 15623634.

55. Pauls K, Jäger R, Weber S et al. Transcription factor AP2gamma, a novel marker of gonocytes and seminomatous germ cell tumors. Int J Cancer. 2005;115:470-477. PMID: 15700319.

56. Biermann K, Klingmüller D, Koch A et al. Diagnostic value of markers M2A, OCT3/4, AP-2gamma, PLAP and c-KIT in the detection of extragonadal seminomas. Histopathology. 2006;49:290-297. PMID: 16918976.

57. Sonne SB, Herlihy AS, Hoei-Hansen CE et al. Identity of M2A (D2-40) antigen and gp36 (Aggrus, T1A-2, podoplanin) in human developing testis, testicular carcinoma in situ and germ-cell tumours. Virchows Arch. 2006;449:200-206. PMID: 16736189.

58. Idrees M, Saxena R, Cheng L, Ulbright TM, Badve S. Podoplanin, a novel marker for seminoma: A comparison study evaluating immunohistochemical expression of podoplanin and OCT3/4. Ann Diagn Pathol. 2010;14:331-336. doi: 10.1016/j.anndiagpath.2010.05.008.

59. Słowikowska-Hilczer J, Walczak-Jedrzejowska R, Kula K. Immunohistochemical diagnosis of preinvasive germ cell cancer of the testis. Folia Histochem Cytobiol. 2001;39:67-72. PMID: 11374842

60. McLachlan R, Rajpert-De Meyts E, Hoei-Hansen C, De Kretser DM, Skakkebæk NE. Histological evaluation of the human testis: approaches to optimizing the clinical value of assessment: Mini review. Hum Reprod. 2007;22:2-16. PMID: 16887924.

61. Oosterhuis JW, Stoop H, Dohle G et al. A pathologist's view on the testis biopsy. Int J Androl. 2011;34:e14-e19. doi: 10.1111/j.1365-2605.2011.01204.x.

62. de Jong J, Stoop H, Gillis AJ et al. Differential expression of SOX17 and SOX2 in germ cells and stem cells has biological and clinical implications. J Pathol. 2008;215:21-30. doi: 10.1002/path.2332.

63. Sonne SB, Perrett RM, Nielsen JE et al. Analysis of SOX2 expression in developing human testis and germ cell neoplasia. Int J Dev Biol. 2010;54:755-760. doi: 10.1387/ijdb.082668ss.

64. Leroy X, Augusto D, Leteurtre E, Gosselin B. CD30 and CD117 (c-kit) used in combination are useful for distinguishing embryonal carcinoma from seminoma. J Histochem Cytochem. 2002;50:283-285. PMID: 11799147.

65. Mosbech CH, Svingen T, Nielsen JE et al. Expression pattern of clinically relevant markers in paediatric germ cell- and sex cord-stromal tumours is similar to adult testicular tumours. Virchows Archiv. 2014;465:567-577. doi: 10.1007/s00428014-1635-1.

66. Jacobsen GK, Jacobsen M. Alpha-fetoprotein (AFP) and human chorionic gonadotropin (HCG) in testicular germ cell tumours. A prospective immunohistochemical study. Acta Pathol Microbiol Immunol Scand A. 1983;91:165-176. PMID: 6190350.

67. Wang F, Liu A, Peng Y et al. Diagnostic utility of SALL4 in extragonadal yolk sac tumors: an immunohistochemical study of 59 cases with comparison to placental-like alkaline phosphatase, alpha-fetoprotein, and glypican-3. Am J Surg Pathol. 2009;33:1529-1539. doi: 10.1097/PAS.0b013e3181ad25d5.
68. Nogales FF, Quiñonez E, López-Marín L, Dulcey I, Preda O. A diagnostic immunohistochemical panel for yolk sac (primitive endodermal) tumours based on an immunohistochemical comparison with the human yolk sac. Histopathology. 2014;65:51-59. doi: 10.1111/his.12373.

69. Alvarado-Cabrero I, Hernández-Toriz N, Paner GP. Clinicopathologic analysis of choriocarcinoma as a pure or predominant component of germ cell tumor of the testis. Am J Surg Pathol. 2014;38:111-118. doi: 10.1097/PAS.0b013e3182a2926e.

70. Lim J, Goriely A, Turner GD et al. OCT2, SSX and SAGE1 reveal the phenotypic heterogeneity of spermatocytic seminoma reflecting distinct subpopulations of spermatogonia. J Pathol. 2011;224: 473-483. doi: 10.1002/path.2919.

71. Stoop H, van Gurp R, de Krijger R et al. Reactivity of germ cell maturation stage-specific markers in spermatocytic seminoma: diagnostic and etiological implications. Lab Invest. 2001;81:919-928. PMID: 11454979.

72. Aubry F, Satie A-P, Rioux-Leclercq $\mathrm{N}$ et al. $M A G E-A 4$, a germ-cell specific marker is differentially expressed in testicular tumours. Cancer. 2001;902:2778-2785. PMID:11753951.

73. Satie A-P, Rajpert-De Meyts E, Spagnoli GC et al. The cancer -testis gene, NY-ESO- 1 is expressed in normal foetal and adult testes, in spermatocytic seminoma and testicular carcinoma in situ. Lab Invest. 2002;82:775-780. PMID: 12065688.

74. Bode PK, Thielken A, Brandt S et al. Cancer testis antigen expression in testicular germ cell tumorigenesis. Mod Pathol. 2014;27:899-905. doi: 10.1038/modpathol.2013.183.

75. Jørgensen A, Nielsen JE, Almstrup K, Toft BG, Petersen BL, Rajpert-De Meyts E. Dysregulation of the mitosis-meiosis switch in testicular carcinoma in situ. J Pathol. 2013;229:588-598. doi: 10.1002/path.4154.

76. Giwercman A, von der Maase H, Skakkebæk NE. Epidemiological and clinical aspects of carcinoma in situ of the testis. Eur Urol. 1993;23:104-110. PMID: 8477770.

77. HolmM,Hoei-HansenCE,Rajpert-DeMeytsE,SkakkebækNE. Increased risk of carcinoma in situ in patients with testicular germ cell cancer with ultrasonic microlithiasis in the contralateral testicle.J Urol. 2003;170:1163-1167. PMID: 14501716.

78. Giwercman A, Marks A, Skakkebæk NE. Carcinoma-in-situ germ-cells exfoliated from seminiferous epithelium into seminal fluid. Lancet. 1988;1:530. PMID: 2893940.

79. Hoei-Hansen CE, Carlsen E, Jorgensen N, Leffers H, Skakkebæk NE, Rajpert-De Meyts E. Towards a non-invasive method for early detection of testicular neoplasia in semen samples by identification of fetal germ cell-specific markers. Hum Reprod. 2007;22:167-173. PMID: 16920726.

80. van Casteren NJ, Stoop H, Dohle GR, de Wit R, Oosterhuis JW, Looijenga LH. Noninvasive detection of testicular carcinoma in situ in semen using OCT3/4. Eur Urol. 2008;54:153-158. PMID: 17996359.

81. Satie AP, Auger J, Chevrier $\mathrm{C}$ et al. Seminal expression of NY-ESO-1 and MAGE-A4 as markers for the testicular cancer. Int J Androl. 2009;32:713-719. doi: 10.1111/j. 1365-2605.2008.00945.x.

82. Nielsen JE, Kristensen DM, Almstrup K et al. A novel double staining strategy for improved detection of testicular carcinoma in situ cells in human semen samples. Andrologia. 2012;44:78-85. doi: 10.1111/j.1439-0272.2010.01108.x.

83. Almstrup K, Lippert M, Mogensen HO et al. Screening of subfertile men for testicular carcinoma in situ by an automated image analysis-based cytological test of the ejaculate. Int J Androl. 2011;34:e21-e30. doi: 10.1111/j.1365-2605.2011.01192.x.

84. Almstrup K, Nielsen JE, Mlynarska $\mathrm{O}$ et al. Carcinoma in situ testis displays permissive chromatin modifications similar to 
immature foetal germ cells. Br J Cancer. 2010;103:1269-1276. doi: $10.1038 /$ sj.bjc.6605880.

85. Wermann H, Stoop H, Gillis AJ et al. Global DNA methylation in fetal human germ cells and germ cell tumours: association with differentiation and cisplatin resistance.J Pathol. 2010;221:433-442. doi: 10.1002/path.2725.

86. Smiraglia DJ, Szymanska J, Kraggerud SM, Lothe RA, Peltomäki P, Plass C. Distinct epigenetic phenotypes in seminomatous and nonseminomatous testicular germ cell tumors. Oncogene. 2002;21:3909-3916. PMID: 12032829.

87. Netto GJ, Nakai Y, Nakayama M et al. Global DNA hypomethylation in intratubular germ cell neoplasia and seminoma, but not in nonseminomatous male germ cell tumors. Mod Pathol. 2008;21:1337-1344. doi: 10.1038/modpathol.2008.127.

88. Ushida H, Kawakami T, Minami K et al. Methylation profile of DNA repetitive elements in human testicular germ cell tumor. Mol Carcinog. 2012;51:711-722. doi: 10.1002/mc. 20831.

89. Kristensen DG, Nielsen JE, Jørgensen A, Skakkebæk NE, Rajpert-De Meyts E, Almstrup K. Evidence that active demethylation mechanisms maintain the genome of carcinoma in situ cells hypomethylated in the adult testis. Br J Cancer. 2014;110:668-678. doi: 10.1038/bjc.2013.727.

90. Kristensen DG, Mlynarska O, Nielsen JE, Jacobsen GK, Rajpert-De Meyts E, Almstrup K. Heterogeneity of chromatin modifications in testicular spermatocytic seminoma point toward an epigenetically unstable phenotype. Cancer Genet. 2012;205:425-431. doi: 10.1016/j.cancergen.2012.05.003.

91. Bartkova J, Moudry P, Hodny Z, Lukas J, Rajpert-De Meyts E, Bartek J. Heterochromatin marks HP1 $\gamma, \mathrm{HP} 1 \alpha$ and H3K9me3, and DNA damage response activation in human testis development and germ cell tumours. Int J Androl. 2011;34:e103-e113. doi: 10.1111/j.1365-2605.2010.01096.x.

92. Eckert D, Biermann K, Nettersheim D et al. Expression of BLIMP1/PRMT5 and concurrent histone $\mathrm{H} 2 \mathrm{~A} / \mathrm{H} 4$ arginine 3 dimethylation in fetal germ cells, CIS/IGCNU and germ cell tumors. BMC Dev Biol. 2008;8:106. doi: 10.1186/1471213X-8-106.

93. Kristensen DG, Skakkebæk NE, Rajpert-De Meyts E, Almstrup K. Epigenetic features of testicular germ cell tumours in relation to epigenetic characteristics of foetal germ cells. Int J Dev Biol. 2013;57:309-317. doi: 10.1387/ijdb.130142ka.
94. Gilligan TD, Seidenfeld J, Basch EM et al, American Society of Clinical Oncology. American Society of Clinical Oncology Clinical Practice Guideline on uses of serum tumor markers in adult males with germ cell tumors. J Clin Oncol. 2010;28:3388-3404. doi: 10.1200/JCO.2009.26.4481.

95. Albers P, Albrecht W, Algaba F et al, European Association of Urology. EAU guidelines on testicular cancer: 2011 update. Eur Urol. 2011;60:304-319. doi: 10.1016/j.eururo.2011.05.038.

96. von Eyben FE, de Graaff WE, Marrink J et al. Serum lactate dehydrogenase isoenzyme 1 activity in patients with testicular germ cell tumors correlates with the total number of copies of the short arm of chromosome 12 in the tumor. Mol Gen Genet. 1992;235:140-146. PMID: 1435725.

97. Novotny GW, Belling KC, Bramsen JB et al. MicroRNA expression profiling of carcinoma in situ cells of the testis. Endocr Relat Cancer. 2012;19:365-379. doi: 10.1530/ERC-11-0271.

98. Palmer RD, Murray MJ, Saini HK et al, Children's Cancer and Leukaemia Group. Malignant germ cell tumors display common microRNA profiles resulting in global changes in expression of messenger RNA targets. Cancer Res. 2010;70:2911-2923. doi: 10.1158/0008-5472.CAN-09-3301.

99. Rijlaarsdam MA, van Agthoven T, Gillis AJ et al. Identification of known and novel germ cell cancer-specific (embryonic) miRs in serum by high-throughput profiling. Andrology. 2015;3:85-91. doi: 10.1111/andr.298.

100. Dieckmann KP, Spiekermann M, Balks T et al. MicroRNAs miR-371-3 in serum as diagnostic tools in the management of testicular germ cell tumours. BrJ Cancer. 2012;107:1754-1760. doi: 10.1038/bjc.2012.469.

101. Gillis AJ, Rijlaarsdam MA, Eini R et al. Targeted serum miRNA (TSmiR) test for diagnosis and follow-up of (testicular) germ cell cancer patients: a proof of principle. $\mathrm{Mol}$ Oncol. 2013;7:1083-1092. doi: 10.1016/j.molonc.2013.08. 002 .

102. Syring I, Bartels J, Holdenrieder S, Kristiansen G, Müller SC, Ellinger J. Circulating serum miRNA (miR-367-3p, miR-371a -3p, miR-372-3p and miR-373-3p) as biomarkers in patients with testicular germ cell cancer.J Urol. 2015;193:331-337. doi: 10.1016/j.juro.2014.07.010.

103. Spiekermann M, Belge G, Winter N et al. MicroRNA miR-371a-3p in serum of patients with germ cell tumours: evaluations for establishing a serum biomarker. Andrology. 2015;3:78-84. doi: 10.1111/j.2047-2927.2014.00269.x.

Submitted: 30 June, 2015

Accepted after reviews: 19 August, 2015 Available as AoP: 24 August, 2015 